\title{
Foreign Policy
}
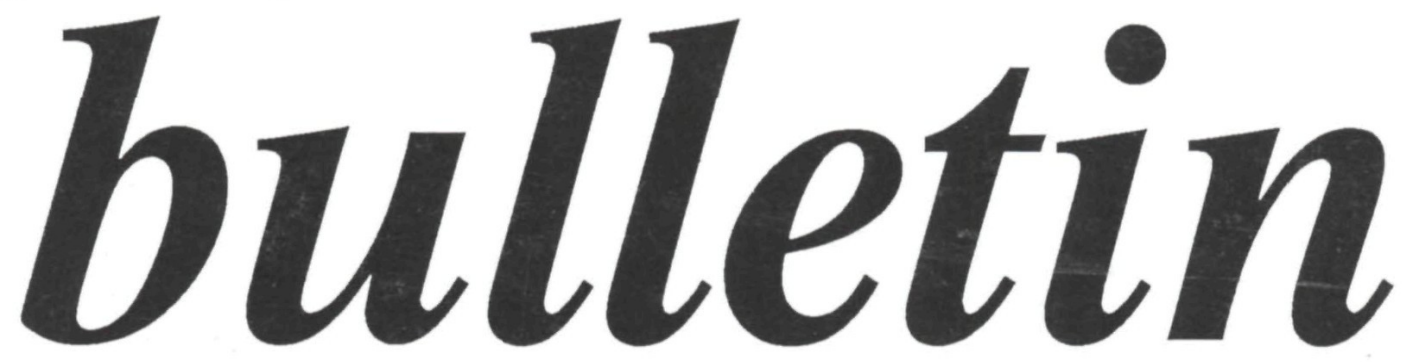

The Documentary Record of United States Foreign Policy/Volume 2/Number 4 \& 5 January/February 1992 March/April 1992

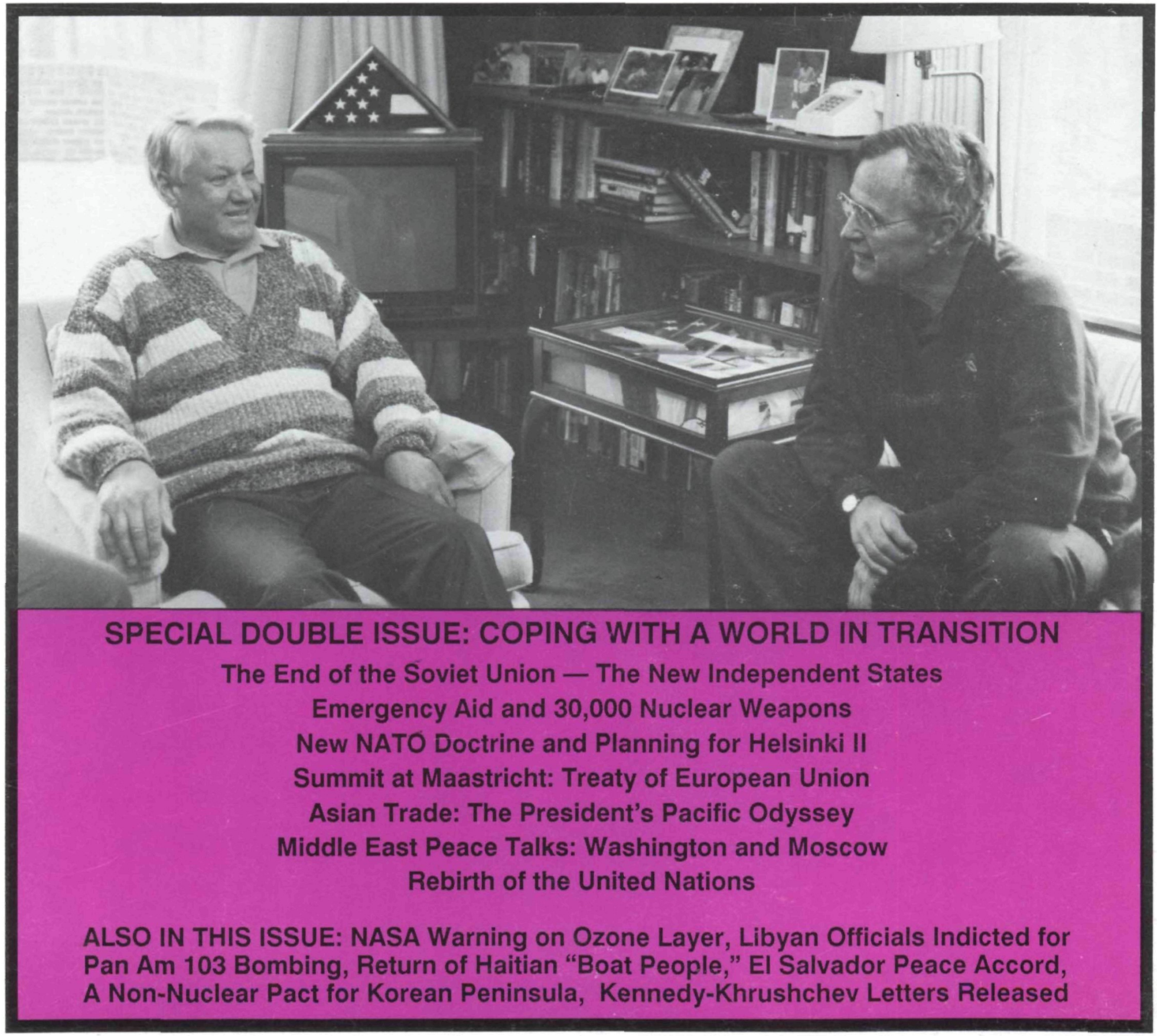




\section{Foreign Policy bulletin}

\section{PHOTO CREDITS:}

1) Cover photo of President Bush and Russian President Boris Yeltsin at Camp David, Maryland, February 1, 1992. DAVID VALDEZ/THE WHITE HOUSE.

2) Page 5 photo of Operation Provide Hope medical supplies, worth nearly $\$ 17$ million, arriving in Kishinev, Moldova, February 10, 1992. A U.S. Air Force C-141B flew them from Rhein Main Airbase in Germany.

DEPARTMENT OF DEFENSE PHOTO/SSGT. DEAN WAGNER.

3) Page 77 photo of first United Nations Security Council meeting of Heads of State and Government, New York, January 31, 1992. U.N. PHOTO 179216/J. ISAAC.

4) Page 87 photo of President Bush and Singapore Prime Minister Goh at press conference, Istana Palace, January 4, 1992. SUSAN BIDDLE/ THE WHITE HOUSE.
Volume 2/Number $4 \& 5$

January/February1992

March/April 1992

The FOREIGN POLICY BULLETIN is published bimonthly (plus annual index) as a private publication of Mediacom, Inc. It uses the same format as the discontinued "Department of State Bulletin" and maintains continuity with that publication while offering additional materials as well. Its purpose is to provide a timely and systematic record of United States foreign policy and of complementary documents from international sources. The BULLETIN's coverage of official U.S. documents includes major addresses, diplomatic statements, and press conferences of the President and the Secretary of State; statements and congressional testimony by the Secretary and other administration officials; treaties and other agreements to which the United States is or may become a party; special reports; and selected press releases issued by the White House, the Department of State, and other agencies. Special features include speeches and other statements by foreign officials concerning U.S. policy; reports and other materials from international organizations relating to major issues confronting U.S. policymakers; and background information about countries of particular interest to U.S. foreign relations.
PAUL E. AUERSWALD

Editor and Publisher

PHILIP AUERSWALD

Business Manager

HUGUETTE NIZARD

Subscriptions Manager

HOPE FUNG

Layout and Typesetting

J. LEONARD MAZUR

Research and Marketing

Consultant

Printed by

PRINTING SERVICE

INTERNATIONAL

ISSN 1052-7036

TAX I.D. NO. 52-1741962
Most of the contents of this publication are official documents in the public domain; individual items may be reprinted and citation of this source is appreciated. However, the compilation of these materials is copyrighted and permission must be obtained to reproduce or reprint numerous pages or entire sections of an issue. Permission to reproduce copyrighted materials from other sources (including photographs credited to commercial vendors) must be obtained from the original source.

INDEXING: Included in the PAIS (Public Affairs Information Service) indexes: the PAIS Bulletin, PAIS on CDROM, and online through Dialog, BRS, and Data-Star.
SUBSCRIPTIONS: Annual subscriptions to the BULLETIN are $\$ 49.00$; outside the U.S. \$63.00. A complete mailing address and payment should be sent to: Subscriptions, Foreign Policy Bulletin, 4812 Butterworth Place N.W., Washington, D.C. 20016. If you have any questions, call (202) 686-5230.

BACK ISSUES: Complete sets of Volume 1 (July 1990-June 1991) can be purchased for $\$ 49.00$ a set. Single copies of any back issue can be purchased for $\$ 12.00$.

CORRESPONDENCE should be ad. dressed to: Foreign Policy Bulletin, 4812 Butterworth Place N.W.,

Washington, D.C. 20016.

Telephone: (202) 686-5230 


\section{ANOTHER SPECIAL DOUBLE ISSUE}

Due to the amazing amount of international activity at the end of 1991 and the beginning of 1992, we are publishing another Special Double Issue including both Volume 2, Number 4 and Volume 2, Number 5 . We were guided in part by the enthusiastic response we received to our double issue on the Persian Gulf War a year ago; we think this issue is even better, because it covers the entire range of global change and upheaval unique to these months. We hope you will derive as much satisfaction from using this double issue as we did from compiling it.

Paul E. Auerswald

Editor 


\section{FEATURE: THE REORGANIZATION OF EUROPE}

\section{Part I. The End of the Soviet Union}

4 President Meets with Russian Foreign Minister Kozyrev, November 26

4 White House Statement on Ukrainian Vote for Independence, December 2

5 Declaration of Leaders of Russia, Ukraine and Belarus, December 8

6 Economic Pact of Russia, Ukraine and Belarus, December 6

6 Official Agreement by Russia, Ukraine and Belarus to Establish the Commonwealth, December 8

7 President Gorbachev's Statement on New Commonwealth, December 9

8 Bush Telephone Conversations With Presidents Gorbachev and Yeltsin, December 13

8 Protocol to Commonwealth Agreement, Eleven Republics, December 21

8 Alma-Ata Declaration, Eleven Republics, December 21

9 Declaration on the Military, Eleven Republics, December 21

9 Declaration on Institutions, Eleven Republics, December 21

9 Declaration on U.N. Membership, Eleven Republics, December 21

9 Declaration on Nuclear Arms: Russia, Belarus, Ukraine, Kazakhstan, December 21

10 President Gorbachev's Televised Statement, December 25

11 President's Statement on Gorbachev Resignation, December 25

12 President Welcomes Commonwealth of Independent States, December 25

13 President's Press Conference, December 26

\section{Part II. The New Independent States: Assistance and Security}

\section{A. Navigating the Transition}

14 White House Statement on Assistance to Soviet Union, Republics, November 20

14 President's Remarks on Developments in U.S.S.R., December 5 and 6

15 CIA Director Comments on Imminent Collapse of Soviet Union, December 10

16 White House Names Coordinators of U.S. Aid, December 12

17 Secretary Baker Calls for Historic Commitment to Aid Soviet Republics, Announces Coordinating Conference, December 12

23 Medical Shipments to U.S.S.R., December 14

23 Chairman of House Armed Services Committee Criticizes Administration Aid Response, December 19

25 Secretary Baker Reports on Trip to Soviet Republics, December 19

27 President's Remarks on Relations with Independent Republics, December 19

27 Treasury Secretary Brady Proposes IMF/World Bank Membership for Former Soviet Republics, January 3

B. Coordinating Conference on Assistance to New Independent States

27 Opening Address by President Bush, January 22

29 Address by Secretary Baker to Opening Session, January 22

31 President Yeltsin's Message to Conference Participants, January 20

31 Joint Press Conference Concluding the Conference, January 23

40 Fact Sheets on Working Groups' Conclusions, January 23

43 Fact Sheets on U.S. Government Activities, January 23

C. Arms Reduction and Nonproliferation Measures

45 President Announces More Arms Cuts, January 28

46 Summary of Unilateral Reductions, January 28

46 Presidents Bush and Yeltsin Meet at Camp David, February 1

48 U.S.-Russia Camp David Declaration, February 1

49 Negotiations Concerning Nuclear Capabilities of Former Soviet Union (Bartholomew), February 5

53 BRIEFS: Senate Ratifies CFE Treaty, President Transmits START Treaty to Senate 


\section{Part III. NATO Summit in Rome: A New Strategic Doctrine}

54 Intervention by President Bush at NATO Summit, November 7

55 Declarations on Peace and Cooperation and on the Soviet Union, NATO Summit, November 8

59 White House Fact Sheet: NATO's New Strategic Concept, November 8

59 French President Mitterrand's Policy Positions at Summit, November 7

60 President's Rome Press Conference, November 8

\section{Part IV. Transatlantic Relations: President Meets with EC Leaders}

61 Remarks at Luncheon Hosted by Netherlands Prime Minister, November 9

63 President's Press Conference with Netherlands Prime Minister and EC Commission President, November 9

\section{Part V. Summit at Maastricht: Treaty on European Union}

65 European Council Presidency Conclusions, December 10

68 Statement by President on Maastricht Summit, December 11

69 Excerpts from Maastricht Agreements

\section{Part VI. CSCE Meeting in Prague: Ten New States Join}

70 Secretary Baker at CSCE Council of Ministers Meeting, January 30

71 Summary of Conclusions, CSCE Council of Ministers Meeting, January 31

74 Prague Document on Further Development of CSCE Institutions and Structures, January 30

\section{BULLETIN SPECIAL: SECURITY COUNCIL SUMMIT MEETING}

77 Statements by Chinese Premier Li Peng (77), French President Francois Mitterrand (79), Russian President Boris Yeltsin (81), President Bush (83), and British Prime Minister Major (85) at Heads of State and Government Meeting of United Nations Security Council

\section{FEATURE: THE PRESIDENT'S PACIFIC ODYSSEY}

\section{Part I. Preliminaries to Trip}

87 White House Announcement of Trip Postponement, November 5

87 President's Press Conference, November 6

88 President's Remarks to Asia Society, November 12

89 Secretary Baker on Asia-Pacific Economic Cooperation, November 11

90 Secretary Baker's Press Conference on Visit to China, November 17

91 President's Remarks Upon Departure, December 30

\section{Australia}

91 President's Remarks to Australian Parliament, January 2

93 President's Press Conference with Australian Prime Minister Keating, January 2

\section{Singapore}

94 President's Press Conference with Singapore Prime Minister Goh, January 4

94 President's Remarks to Singapore Lecture Group, January 4

96 President Offers U.S.-Asia Environmental Partnership, January 4 


\section{Republic of Korea}

96 President's Press Conference with South Korean President Roh, January 6

97 U.S.-Korea Science and Technology Agreement, January 6

97 President's Address to Korean National Assembly, January 6

98 President's Remarks to U.S. Chamber of Commerce, Seoul, January 6

\section{Japan}

99 President's Remarks at Toys-R-Us Opening, January 7

99 President Bush and Prime Minister Miyazawa Announce Strategy for World Growth, January 8

100 Fact Sheet: U.S.-Japan Strategy for World Growth, January 8

100 U.S. Remarks at State Dinner Hosted by Prime Minister Miyazawa,January 8

101 President's Press Conference with Prime Minister Miyazawa, January 9

102 Tokyo Declaration on the U.S.-Japan Global Partnership, January 9

104 Fact Sheet: U.S.-Japan Global Partnership Action Plan, January 9

\section{Africa}

106 U.S. Policy Summary: Sub-Saharan Afritca

107 BRIEFS: South Africa, Somalia, Togo, Zaire, Kenya, Zambia

\section{East Asia}

109 Bilateral Talks with Vietnam and Laos

109 Cambodia Embargo Lifted

110 South and North Korea Agree to Ban Nuclear Weapons

\section{Environment}

111 SPECIAL: NASA Report on Ozone Layer Depletion Over Northern and Temperate Latitudes

112 White House Announces Accelerated Phase-Out of Ozone-Depleting Substances

\section{Europe}

113 U.S. Welçomes U.N. Efforts to Establish Cease-Fire in Yugoslavia

113 President Reports to Congress on Cyprus Question

\section{International Law}

114 Individual Claims Against Iraq

114 BRIEFS: North Pacific Salmon Convention, U.S.-Venezuela
Drug Interdiction Agreement, U.S.- Japan Driftnet Fishing Moratorium

\section{Middle East}

115 Bilateral Peace Talks in Washington (U.S., Israel, Palestinians)

118 Multilateral Talks in Moscow (U.S., Russia, Israel, Saudi Arabia)

121 UNGA Repeals "Zionism is Racism" Resolution (U.S., Israel)

122 Security Council Condemns Deportations by Israel (U.S., Text of Resolution)

122 President's Report to Congress on Iraq

\section{Terrorism}

124 Libyan Officials Indicted for Pan Am 103 Bombing (Barr)

124 Joint Declarations on Libyan Bombings (U.S., U.K., France)

125 Release of American Hostages in Lebanon (Bush)

\section{Trade}

126 Fact Sheets on U.S.-Japan Economic Relations

129 U.S. Statements on Foreign Direct Investment in U.S.

130 EC Statement on Foreign Direct Investment in U.S.
130 Fact Sheet on Foreign Direct Investment

\section{United Nations}

132 Boutros-Ghali Appointed U.N. Secretary-General

\section{Western Hemisphere}

133 Peace Agreement in El Salvador (Baker)

135 Continuing Efforts to Restore Democracy to Haiti (Einaudi)

136 Return of "Boat People" to Haiti (Gelbard, Fascell, Baker, Berman)

\section{Treaties}

140 Current Actions

\section{Press Documents}

145 Department of State

\section{Publications}

148 Kennedy-Khrushchev Cuban Missile Crisis Correspondence

148 U.S.S.R. and Eastern Europe (Kimball)

148 Syria and Middle East Peace Process (Drysdale and Hinnebusch)

149 Index 